\title{
Mark Hoddle: Smiting weevils
}

$\mathrm{M}$ ark Hoddle's research article in this issue documents a major achievement in invasive species control - a successful eradication, in this case of the Asian palm weevil, Rhynchophorus vulneratus, from Laguna Beach.

Hoddle, a UC Riverside-based entomology specialist and director of the Center for Invasive Species Research (CISR), is now working to address another weevil infestation.

This time, the invader is Rhynchophorus palmarum, the South American palm weevil. Over decades, the insect has steadily increased its range northward in Mexico, enabled by abundant plantings of Canary Island palms which the weevil infests in irrigated desert areas. These unnatural oases have provided stepping stones for the weevil through inhospitable habitat all the way to California.

The South

The South American palm weevil, Rhynchophorus palmarum (actual size), infests the Canary Island palm, a common landscape tree in California.

\section{1 just north of the border near San Dieg} tion, a two-year, federally supported trapping program concluded that the infestation hadn't spread beyond San Diego and Imperial counties.

After 2013, funding for the trapping effort ran out, leaving no system for monitoring the weevil. After a visit to Tijuana last May, Hoddle found 125 weevil-killed palms in a day of driving around the city with a colleague from Tijuana. After this he decided to take matters into his own hands. The following month, he and his wife, Christina - also an entomology researcher at UC Riverside and a co-author on the research paper in this issue - began a family mission to assess the state of the infestation in California.

"We are spending a significant amount of our spare time trapping in San Diego," he said. They bring along their threeyear-old son, Nicholas, who likes hunting for the satisfyingly large black weevils.

"It was easy to get him on board, because we are looking for super cool big beetles," said Hoddle, who grew up in New Zealand and has loved hunting for bugs since he was a small boy.

Because Canary Island palms are such a ubiquitous part of the California landscape, they could provide food for weevil invasion all the way up to Northern California. Laboratory tests Hoddle has conducted using "flight mills" — treadmills for

UC Riverside entomology specialist Mark Hoddle and his son, Nicholas, set weevil traps along the Sweetwater River Trail in San Diego County, a natural area where weevils have infested many unmanaged Canary Island palms. flying insects - have shown that the weevils have the potential to fly tens of miles in a day. The weevil is also known to carry a pathogen known as the red ring nematode which also infects the Canary Island palm, making weevil infestations particularly deadly. The nematode hasn't yet been found on the weevils trapped in the United States, but Hoddle says it's probably only a matter of time until it appears.

So far, the Hoddle family monitoring program hasn't found any South American palm weevils north of San Diego County. But the insect appears to be well-entrenched in some areas, such as the Sweetwater River Trail, a natural area near Bonita in San Diego County where many palms grow wild and unmanaged, amidst thickets of willows. Areas like this provide reservoirs for the weevil population to grow and spread into new areas. As one part of their monitoring effort, the Hoddles have assigned GPS coordinates to 300 trees in and near the Sweetwater River Trail area, and are monitoring them to better understand the dynamics of the weevil's spread. Hoddle will be using dronemounted cameras to do regular monitoring of the trees in infested areas, many of which are difficult to reach.

Hoddle has been working with the California Department of Food and Agriculture (CDFA) to draw attention to the infestation, yielding media coverage all the way up to an article in the New York Times. People finding a South American palm weevil

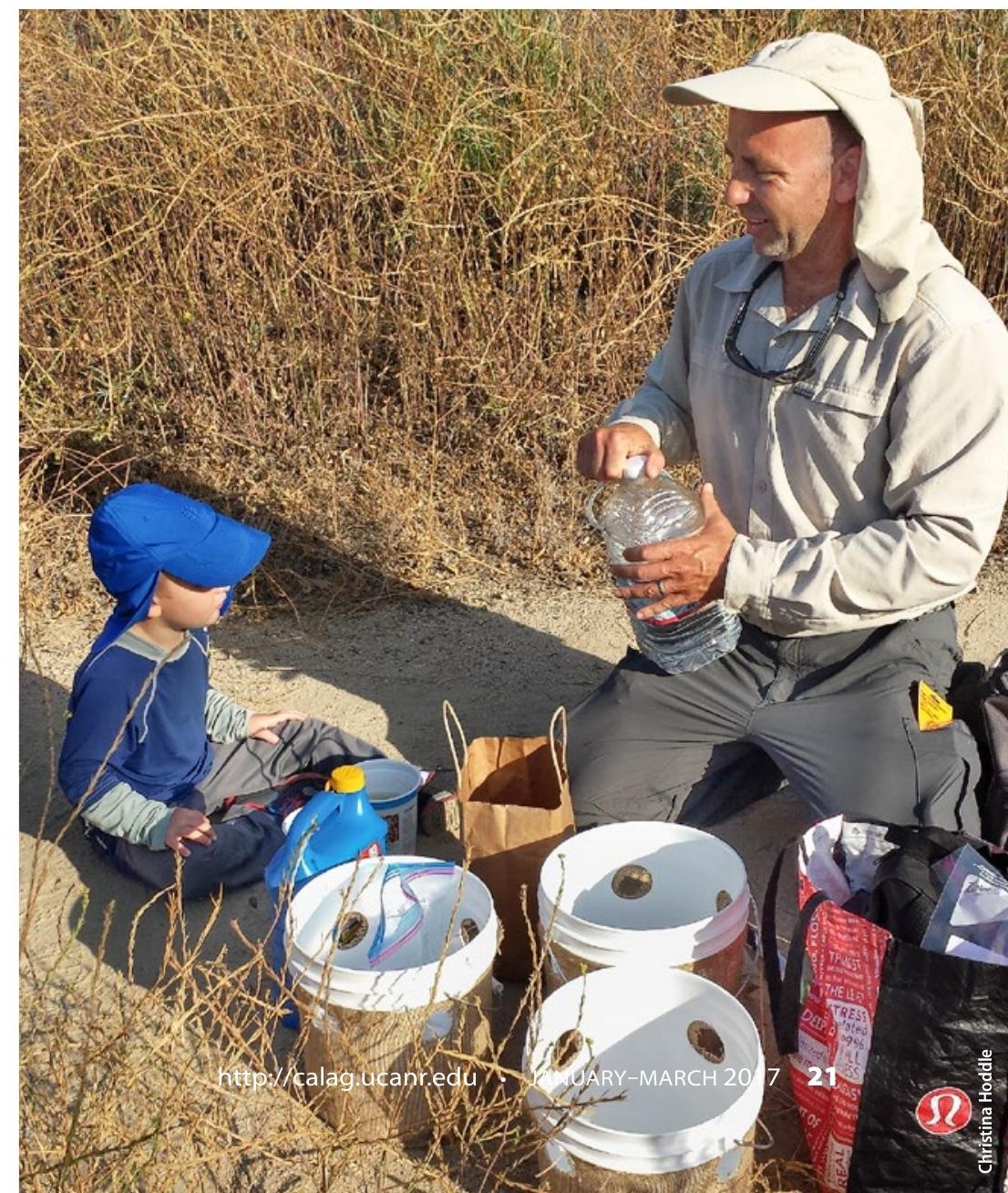


